\title{
Diagnostic, Prognostic and Predictive Immunohistochemistry in Malignant Melanoma of the Skin
}

\author{
Diagnostická, prognostická a prediktivní imunohistochemie \\ při maligním melanomu kůže
}

\author{
Roncati L. \\ Department of Diagnostic and Clinical Medicine and of Public Health, Institute of Pathology, University of Modena and Reggio Emilia, Modena, Italy
}

Immunohistochemistry (IHC) is an excellent technique for labeling detection of selected cell proteins, which exploits the principle of antigenantibody specific binding in biological tissues [1]. First implemented by Albert Coons in 1941 [2], over time it had achieved great success for diagnostic purposes (diagnostic IHC), then for prognostic ones (prognostic IHC) [3]. Several molecular pathways are altered in skin melanoma and non-melanoma skin cancers and some of these can be targeted in oncotherapy [1]. Therefore, IHC application has increased and can predict those tumors which are likely to respond to targeted cancer therapy (predictive IHC), by detecting the presence or high expression levels of altered gene products.

\section{Diagnostic IHC}

Among themostused diagnosticmarkers for melanoma cells, there are: anti-S100, anti-MelanA, anti-MITF (microphthalmia transcription factor), anti-Sox10 (sryrelated hmg-box 10), anti-Melanosome and melanoma cocktail. Quite similar to calmodulin, S100 protein is a low-molecular weight protein characterized by two calcium-binding sites in a "helix-loop-helix" conformation [4]. It in fact plays crucial roles in calcium homeostasis, cytoskeleton dynamics, protein phosphorylation, cell growth, cell differentiation and inflammatory response [5]. It is soluble in $100 \%$ ammonium sulphate at neutral $\mathrm{pH}$, hence its acronym [4]. S100 protein is not specific for the melanocyte lineage, being present in all cells derived from the neural crest [6]. MelanA protein, also known as MART1 (melanoma antigen recognized by $T$ cells 1 ), is a transmembrane protein made up by 118 amino acids; its fragment consisting of nine amino acids (27-35) is bound by MHC (major histocompatibility complex) class I molecules, which present it to cytotoxic T-lymphocytes on the cell surface [7]. The MelanA antigen is more specific for the melanocyte lineage than S100, and its diagnostic utility resides in staining melanoma cells in a homogeneous manner from the epidermis downward, allowing easy recognition of lentiginous or pagetoid diffusion and sub-epidermal foci of microinvasion [1]. MelanA expression is regulated by MITF, which is a basic "helix-loop-helix" leucine zipper transcription factor involved in lineagespecific regulation pathways of many cell types, melanocytes included [8]. In humans, mutations of MITF can lead to melanoma, Waardenburg syndrome and Tietz syndrome [9]. MITF IHC is sensitive but not specific since it can be expressed also by osteoclasts and mast cells [10]. In melanocytic cells, there is
The author declares he has no potential conflicts of interest concerning drugs, products, or services used in the study.

Autor deklaruje, že $v$ souvislosti s predmětem studie nemá žádné komerční zájmy.

The Editorial Board declares that the manuscript met the ICMJE recommendation for biomedical papers.

Redakční rada potvrzuje, že rukopis práce splnil ICMJE kritéria pro publikace zasílané do biomedicínských časopisů.

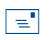

Dr. Luca Roncati, MD, PhD

Department of Diagnostic and Clinical

Medicine and of Public Health Institute of Pathology

University of Modena and Reggio

Emilia

Policlinico Hospital

I-41124 Modena (MO), Italy

e-mail: emailmedical@gmail.com

Submitted/Obdrženo: 25. 12. 2017

Accepted/Přijato: 4. 1. 2018

doi: 10.14735/amko2018152

evidence that MITF may also regulate the SOX10 gene expression and, therefore, SOX10 IHC has been recently introduced for diagnostic purposes [11]. Melanosomes are cell organelles deputy to synthesis and storage of melanin in normal melanocytes and melanoma 


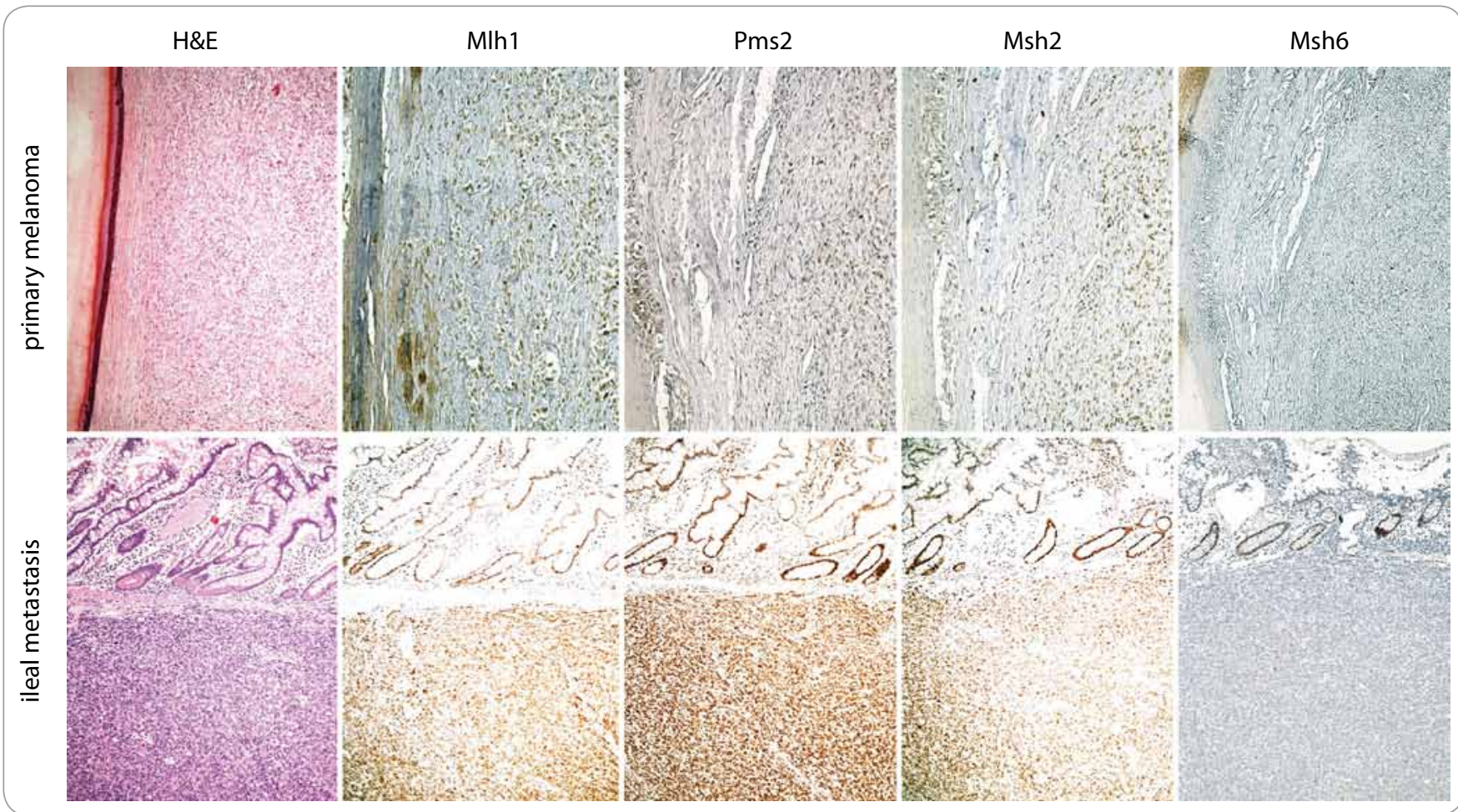

Fig. 1. Subungual melanoma with metastatic spreading to brain and ileum in a middle aged female patient treated with significant benefit by pembrolizumab - if compared to Mlh1, Pms2 and Msh2 status, an exclusive loss of IHC expression for Msh6 protein has been ascertained. The ileal metastasis, here illustrated, and the brain one show the same IHC profile of the primary melanoma; they are in fact characterized by an exclusive loss of IHC expression for Msh6 protein, if compared to Mlh1, Pms2 and Msh2 status. At present, the patient is still alive and in complete response with a progression free survival and an overall survival of 956 days and 2546 days, resp. (H\&E - hematoxylin and eosin; Mlh1 - clone M1, Ventana; Pms2 - clone EPR3947, Ventana; Msh2 - clone G219-1129, Ventana; Msh6 - clone 44, Ventana; chromogen $-3,3^{\prime}$ diaminobenzidine tetrahydrochloride hydrate; original magnification - 10x).

cells, from which melanin can be released to adjacent keratinocytes [12]. $\mathrm{Hmb} 45$ (human melanoma black 45) is the monoclonal antibody which reacts precisely against melanosomes [13], its staining pattern is usually zonal/shallow in nevus and diffuse/deep in melanoma, making differential diagnosis easier [13]. Inside melanosomes, the melanin production is catalyzed by the rate-limiting oxidative enzyme tyrosinase - for this reason, the anti-Tyrosinase monoclonal antibody is one of the melanoma cocktail components, together with Mart1 and Hmb45 [14].

\section{Prognostic IHC}

IHC has a limited value in determining the prognosis of skin melanoma, which is in fact related to microstaging attributes, such as Breslow's depth, Clark's level, ulceration, regression, mitotic hot-spot, growth phase, lymphovascular invasion and tumor-infiltrat- ing lymphocytes [15-23]. The current AJCC (American Joint Committee on Cancer) staging system uses Breslow's depth and ulceration as main prognostic determinants [24-26]. In this context, IHC can facilitate a better definition of the abovementioned histopathological attributes; for example, juxtaposing the labeling index of Ki67 proliferative antigen to the mitotic count [1], or disclosing the type of growth phase by evaluating the expression of the antiapoptotic molecule cyclin D1 [1,27-30], or identifying the subtypes and rates of lymphocytes around and inside the tumor, with particular reference to CD4CD8+ T-killer lymphocytes [31-34], or highlighting the hematic and lymphatic endothelia of the capillaries involved by neoplastic spread [35]. To reach this last goal, anti-Pecam1 (platelet endothelial cell adhesion molecule 1) or anti-Podoplanin antibodies can be used, resp. [36]. Among the tumor suppressor genes, CDKN2A encodes for p16ink4a protein, which plays an important role in cell cycle regulation by inhibiting cell cycle progression from $\mathrm{G} 1$ to $S$ phase [37]. The CDKN2A gene is frequently altered in malignant melanoma; therefore, IHC for the mutant form of p16ink4a can be used in the diagnosis of microinvasive melanoma, in order to distinguish it from in situ melanoma or dysplastic nevus, both characterized by a lower immunolabeling and an indolent course [1].

\section{Predictive IHC}

Today, the main genes involved in melanoma genesis susceptible to predictive IHC investigation are - BRAF, NRAS, CDK4, KIT [38]. Mutations in BRAF and NRAS are responsible for $50 \%$ and $20 \%$ of all melanomas [39]. Vemurafenib and dabrafenib are V600 mutant B-Raf inhibitors approved for the treatment of late-stage melanoma [40]. The 
growth signal transduction triggered by V600 mutant B-Raf can be also mitigated inhibiting MEK (MAPK/ERK kinase) proteins, members of MAPK (mitogen-activated protein kinase) signaling cascade, thus favoring cell cycle block and apoptosis [40]. The most known MEK inhibitors used in the treatment of metastatic melanoma are trametinib and cobimetinib [41]. Binimetinib, another MEK inhibitor, has been tested in a randomized phase III clinical trial for $\mathrm{N}$-Ras Q61 mutant melanoma, becoming the first molecularly targeted therapy for NRAS mutant patients [42]. Palbociclib and ribociclib are Cdk4 inhibitors that are under study for melanoma and other drug resistant tumors, such as estrogen receptor positive breast cancer $[43,44]$. Imatinib and nilotinib are Kit inhibitors available if necessary; the former is active when the mutation occurs in exon 11 of $K I T$, while the latter when it occurs in exon 17 [45]. More recently, a lot of attention has been paid to melanoma immunotherapy, it is a type of passive immunotherapy aimed to enhance preexisting anti-tumor responses of the organism [46]. In this regard, two molecules, Ctla-4 and PD1, have attracted interest of many researchers [47]. Ctla-4 is a surface receptor expressed by activated T-lymphocytes, able to transmit an inhibitory signal of self-tolerance to T-lymphocytes, functioning as an immune checkpoint for normal and neoplastic cells [48]. Ipilimumab is the monoclonal antibody developed to stop the above-mentioned inhibitory signal by binding to Ctla-4. This event is preliminary to melanoma cell destruction by cytotoxic T-lymphocytes [49]. PD1 is a surface receptor of activated T-lymphocytes, which plays an important role in down-regulation of the immune system and promoting self-tolerance [50]. Its ligand, known by the acronym PD-L1 (programmed death-ligand 1), is highly expressed in $40-50 \%$ of melanoma and, hence, the role of PD1 in melanoma immune evasion is now well established [51]. Nivolumab and pembrolizumab are anti-PD1 human monoclonal immunoglobulin G4 capable to block the interaction between PD1 and PD-L1 (immune checkpoint blockade), favoring the melanoma cell attack by T-cells [52]. In 2017, the Food and Drug Administration has approved the use of pembrolizumab also for unresectable or metastatic solid tumors with mismatch repair deficiency or microsatellite instability [53]. Strong evidence showed that microsatellite instability is a frequent condition in malignant melanoma, as well [54]. In line with what has been recently hypothesized by other authors $[55,56]$, my working group has noticed, in daily clinical practice, that the best therapeutic results of pembrolizumab occur in those patients affected by melanomas with mismatch repair deficiency (Fig. 1). Therefore, before choosing the most suitable treatment, the bioptic specimen should be also tested for Mlh1, Msh2, Msh6 and Pms 1 [57], the well-known DNA mismatch repair proteins in humans.

\section{Acknowledgements}

The author would express his thanks to Mrs. Paola Manni for her technical and support.

\section{References}

1. Roncati L, Piscioli F, Pusiol T et al. Microinvasive radial growth phase of cutaneous melanoma: a histopathological and immunohistochemical study with diagnostic implications. Acta Dermatovenerol Croat 2017; 25(1): 39-45

2. Coons AH, Creech HJ, Jones RN. Immunological properties of an antibody containing a fluorescent group. Proc Soc Exp Biol Med 1941; 47: 200-202.

3. Roncati L, Manenti A, Sighinolfi P. Immunohistochemical improvement in the analysis of the lymphatic metastases from lung carcinoma. Ann Thorac Surg 2014 97(1): 380-381. doi: 10.1016/j.athoracsur.2013.06.072.

4. Marenholz I, Heizmann CW, Fritz G. S100 proteins in mouse and man: from evolution to function and pathology (including an update of the nomenclature). Biochem Biophys Res Commun 2004; 322(4): 1111-1122. doi: 10.1016/j.bbrc.2004.07.096.

5. Donato R. Intracellular and extracellular roles of S100 proteins. Microsc Res Tech 2003; 60(6): 540-551. doi 10.1002/jemt.10296.

6. Nonaka D, Chiriboga L, Rubin BP. Differential expres sion of S100 protein subtypes in malignant melanoma and benign and malignant peripheral nerve sheath tumors. J Cutan Pathol 2008; 35(11): 1014-1019. doi: 10.1111/j.1600-0560.2007.00953.x.

7. Bioley G, Jandus C, Tuyaerts $S$ et al. Melan-A/MART-1 specific CD4 T cells in melanoma patients: identification of new epitopes and ex vivo visualization of specific $T$ cells by MHC class II tetramers. J Immunol 2006; 177(10): 6769-6779. doi: 10.1111/j.1600-0560.2007.00953.x.

8. Du J, Miller AJ, Widlund HR et al. MLANA/MART1 and SILV/PMEL17/GP100 are transcriptionally regulated by MITF in melanocytes and melanoma. Am J Pathol 2003, 163(1): 333-343. doi: 10.1016/50002-9440(10)63657-7.

9. Léger S, Balguerie X, Goldenberg A et al. Nove and recurrent non-truncating mutations of the MITF basic domain: genotypic and phenotypic variations in
Waardenburg and Tietz syndromes. Eur J Hum Genet 2012; 20(5): 584-587. doi: 10.1038/ejhg.2011.234. 10. Hershey CL, Fisher DE. Mitf and Tfe3: members of a b-HLH-ZIP transcription factor family essential for osteoclast development and function. Bone 2004; 34(4): 689-696. doi: 10.1016/j.bone.2003.08.014

11. Tudrej KB, Czepielewska E, Kozłowska-Wojciechowska M. SOX10-MITF pathway activity in melanoma cells. Arch Med Sci 2017; 13(6): 1493-1503. doi: 10.5114/aoms. 2016.60655

12. Wasmeier C, Hume AN, Bolasco G et al. Melanosomes at a glance. J Cell Sci 2008; 121(24): 3995-3999. doi: 10.1242/jcs.040667.

13. Kapur RP, Bigler SA, Skelly M et al. Anti-melanoma monoclonal antibody HMB45 identifies an oncofetal glycoconjugate associated with immature melanosomes. J Histochem Cytochem 1992; 40(2): 207-212. doi: 10.1177/40.2.1552165

14. Clarkson KS, Sturdgess IC, Molyneux AJ. The usefulness of tyrosinase in the immunohistochemical assessment of melanocytic lesions: a comparison of the novel T311 antibody (anti-tyrosinase) with S-100, HMB45, and A103 (anti-melan-A). J Clin Pathol 2001; 54(3): 196-200. 15. Roncati L, Piscioli F, Pusiol T. The significance of regression in thin melanoma of the skin. Ir J Med Sci 2017; 187(1): 95-96. doi: 10.1007/s11845-017-1612-1.

16. Roncati L, Vergari B, Del Gaudio A. The, all-or-none law' applied to the vertical growth phase of cutaneous malignant melanoma. Chonnam Med J 2017; 53(3): 234-235. doi: 10.4068/cmj.2017.53.3.234.

17. Roncati L, Pusiol T, Piscioli F. Prognostic predictors of thin melanoma in clinico-pathological practice. Acta Dermatovenerol Croat 2017: 25(2): 159-160

18. Roncati L, Piscioli F, Pusiol T. Clinical application of the unifying concept of cutaneous melanoma. Chonnam Med J 2017; 53(1): 78-80. doi: 10.4068/cmj.2017.53.1.78. 19. Piscioli F, Pusiol T, Roncati L. Wisely choosing thin melanomas for sentinel lymph node biopsy. J Am Acad Dermatol 2017; 76(1): e25. doi: 10.1016/j.jaad.2016.08.069. 20. Roncati L, Piscioli F, Pusiol T. SAMPUS, MELTUMP and THIMUMP - Diagnostic categories characterized by uncertain biological behavior. Klin Onkol 2017; 30(3): 221-223. doi: 10.14735/amko2017221.

21. Piscioli F, Pusiol T, Roncati L. Histopathological determination of thin melanomas at risk for metastasis. Melanoma Res 2016; 26(6): 635. doi: 10.1097/CMR.000 0000000000288

22. Piscioli F, Pusiol T, Roncati L. Nowadays a histological sub-typing of thin melanoma is demanded for a proper patient management. J Plast Reconstr Aesthet Surg 2016; 69(11): 1563-1564. doi: 10.1016/j.bjps.2016.08.026.

23. Pusiol T, Piscioli F, Speziali $L$ et al. Clinical features, dermoscopic patterns, and histological diagnostic model for melanocytic tumors of uncertain malignant potential (MELTUMP). Acta Dermatovenerol Croat 2015; 23(3): 185-194.

24. Piscioli F, Pusiol T, Roncati L. Thin melanoma subtyping fits well with the American Joint Committee on Cancer staging system. Melanoma Res 2016; 26(6): 636. doi: 10.1097/CMR.0000000000000301.

25. Piscioli F, Pusiol T, Roncati L. Critical points of T1 stage in primary melanoma. Melanoma Res 2017; 27(4): 399. doi: 10.1097/CMR.0000000000000357.

26. Roncati L, Pusiol T, Piscioli F. Up-to-date proposal for a histologic subcategorization of thin melanomas. Adv Anat Pathol 2017. doi:10.1097/PAP.0000000000000148. 27. Roncati L, Piscioli F, Pusiol T. The importance of mitotic rate reporting in primary cutaneous melanoma. J Surg Oncol 2017; 116(7): 958-959. doi: 10.1002/jso.24738. 28. Roncati L, Piscioli F, Pusiol T. Surgical outcomes reflect the histological types of cutaneous malignant melanoma. J Eur Acad Dermatol Venereol 2017; 31 (6): e279-e280. doi: $10.1111 / \mathrm{jdv} .14023$ 
29. Roncati L, Piscioli F, Pusiol T. Sentinel lymph node in thin and thick melanoma. Klin Onkol 2016; 29(5): 393-394. 30. Roncati L, Piscioli F, Pusiol T. Current controversies on sentinel node biopsy in thin and thick cutaneous melanoma. Eur J Surg Oncol 2017; 43(2): 506-507. doi: 10.1016/j.ejso.2016.09.014

31. Roncati L, Manenti A, Piscioli F et al. The immune score as a further prognostic indicator in carcinoid tumors. Chest 2017; 151(5): 1186. doi: 10.1016/j.chest.2016.10. 032.

32. Roncati L, Manenti A, Piscioli F et al. Immunoscoring the lymphocytic infiltration in carcinoid tumours. Histopathology 2017; 70(7): 1175-1177. doi: 10.1111/his.13168

33. Roncati L, Manenti A, Farinetti A et al. The association between tumor-infiltrating lymphocytes (TILs) and metastatic course in neuroendocrine neoplasms. Surgery 2016; 160(6): 1709. doi: 10.1016/j.surg.2015.12.030.

34. Roncati L, Barbolini G, Piacentini F et al. Prognostic factors for breast cancer: an immunomorphological update. Pathol Oncol Res 2016; 22(3): 449-452. doi: 10.1007/s12253-015-0024-7.

35. Piscioli F, Pusiol T, Roncati L. Diagnostic disputes regarding atypical melanocytic lesions can be solved by using the term MELTUMP. Turk Patoloji Derg 2016; 32(1): 63-64. doi: 10.5146/tjpath.2015.01330.

36. Piscioli F, Pusiol T, Roncati L. Diagnostic approach to melanocytic lesion of unknown malignant potential. Melanoma Res 2016; 26(1): 91-92. doi: 10.1097/CMR.000 0000000000215 .

37. Roncati L, Barbolini G, Sartori G et al. Loss of CDKN2A promoter methylation coincides with the epigenetic transdifferentiation of uterine myosarcomatous cells. Int J Gynecol Pathol 2016; 35(4): 309-315. doi: 10.1097/PGP. 0000000000000181

38. Zhang D, Zhu R, Zhang $H$ et al. MGDB: a comprehensive database of genes involved in melanoma. Database (Oxford) 2015; 2015: pii: bav097. doi 10.1093/database/bav097.
39. Lovly CM, Dahlman KB, Fohn LE et al. Routine multiplex mutational profiling of melanomas enables enrollment in genotype-driven therapeutic trials. PLoS One 2012; 7(4): e35309. doi: 10.1371/journal.pone.0035309.

40. Wong DJ, Ribas A. Targeted therapy for melanoma. Cancer Treat Res 2016; 167: 251-262. doi: 10.1007/978-3319-22539-5_10.

41. Lulli D, Carbone ML, Pastore S. The MEK inhibitors trametinib and cobimetinib induce a type I interferon response in human keratinocytes. Int J Mol Sci 2017 18(10). doi:10.3390/ijms18102227.

42. Queirolo P, Spagnolo F. Binimetinib for the treatment of NRAS-mutant melanoma. Expert Rev Anticance Ther 2017; 17(11): 985-990. doi: 10.1080/1473 7140.2017.1374177.

43. Costa R, Costa RB, Talamantes SM et al. Meta-analysis of selected toxicity endpoints of CDK4/6 inhibitors: palbociclib and ribociclib. Breast 2017; 35: 1-7. doi: 10.1016/j.breast.2017.05.016

44. Roncati L, Barbolini G, Gatti AM et al. The uncontrolled sialylation is related to chemoresistant metastatic breast cancer. Pathol Oncol Res 2016; 22(4): 869-873. doi: 10.1007/s12253-016-0057-6

45. Murer C, Kränzlin-Stieger P, French LE et al Successfu treatment with imatinib after nilotinib and ipilimumab in a c-kit-mutated advanced melanoma patient: a case report. Melanoma Res 2017; 27(4): 396-398. doi: 10.1097/ CMR.0000000000000358

46. Najem A, Krayem M, Perdrix A et al. New drug combination strategies in melanoma: current status and future directions. Anticancer Res 2017; 37(11): 5941-5953. doi: 10.21873/anticanres.12041.

47. Karlsson AK, Saleh SN. Checkpoint inhibitors fo malignant melanoma: a systematic review and metaanalysis. Clin Cosmet Investig Dermatol 2017; 10 325-339. doi: 10.2147/CCID.S120877.

48. Walunas TL, Lenschow DJ, Bakker CY et al. CTLA-4 can function as a negative regulator of T cell activation. Immunity 1994; 1(5): 405-413.
49. Letendre P, Monga V, Milhem M et al. I pilimumab: from preclinical development to future clinical perspectives in melanoma. Future Oncol 2017: 13(7): 625-636. doi: 10.2217/fon-2016-0385

50. Francisco LM, Sage PT, Sharpe AH. The PD-1 pathway in tolerance and autoimmunity. Immunol Rev 2010; 236: 219-242. doi: 10.1111/j.1600-065X.2010.00923.x.

51. Wang $X$, Teng $F$, Kong $L$ et al. PD-L1 expression in human cancers and its association with clinical outcomes. Onco Targets Ther 2016; 9: 5023-5039. doi: 10.2147/OTT. S105862.

52. Prasad V, Kaestner V. Nivolumab and pembrolizumab: monoclonal antibodies against programmed cell death-1 (PD-1) that are interchangeable. Semin Oncol 2017; 44(2): 132-135. doi: 10.1053/j.seminoncol.2017. 06.007.

53. Syn NL, Teng MWL, Mok TSK et al. De-novo and acquired resistance to immune checkpoint targeting. Lancet Oncol 2017; 18(12): e731-e741. doi: 10.1016/ S1470-2045(17)30607-1.

54. Kubeček $\mathrm{O}$, Kopecký J. Microsatellite instability in melanoma: a comprehensive review. Melanoma Res 2016: 26(6): 545-550. doi: 10.1097/CMR.0000000000000298.

55. Kim ST, Klempner SJ, Park SH et al. Correlating programmed death ligand 1 (PD-L1) expression, mismatch repair deficiency, and outcomes across tumor types: implications for immunotherapy. Oncotarget 2017; 8(44): 77415-77423. doi: 10.18632/oncotarget.20 492.

56. Kubecek O, Trojanova P, Molnarova V et al. Microsatellite instability as a predictive factor for immunotherapy in malignant melanoma. Med Hypotheses 2016; 93: 74-76. doi: 10.1016/j.mehy.2016.05.023

57. Roncati L, Manenti A, Pusiol T et al. Testosterone aromatization to estradiol in course of ovarian functioning Brenner tumor associated with endometrial carcinoma and endometriosis (Roncati-Manenti triad). Int J Gynecol Cancer 2016; 26(8): 1461-1464. doi: 10.1097/IGC.0000000000000779 